\title{
KEARIFAN LOKAL MASYARAKAT ADAT CEREKANG DALAM MENJAGA DAN MELESTARIKAN HUTAN ADAT DI DESA MANURUNG KABUPATEN LUWU TIMUR
}

\section{Local Wisdom of Cerekang Indigenous People in Maintaining and Preserving Customary Forests in Manurung Village, East Luwu Regency}

\author{
Maria $^{1}$, Hadijah Azis K², Taskur ${ }^{3}$. \\ Program Studi Kehutanan, Fakultas Kehutanan, Universitas Andi Djemma Palopo \\ mariaforestry@gmail.com
}

\begin{abstract}
The local wisdom of indigenous Cerekang peoples, especially in maintaining and preserving customary forests, is very much needed for the forest's survival and function. This research aims to find out the local wisdom of the Cerekang indigenous people and their role in protecting and preserving customary forests. The research was conducted from September to December 2020 in Manurung Village, Malili District, East Luwu Regency. The data collected consists of the form of local wisdom of the Cerekang indigenous people. The research method used is in-depth interviews with snowball techniques (snowball sampling) to key informants, including customary leaders, community leaders, village government, and communities living around typical forests. Data were analyzed using qualitative descriptive techniques. The results obtained are the local wisdom of the Cerekang customary community in the form of division of customary territories for traditional ceremonies carried out by customary leaders, recommendations and prohibitions on entering customary forests carelessly, and several myths that if violated will damage the environmental ecosystem and bring disaster. This local wisdom plays a very important role in preserving the Cerekang customary forest because the Cerekang indigenous people highly uphold existing local wisdom. The indigenous people believe that if any local wisdom is violated, there will be sanctions or disasters will come.
\end{abstract}

Keywords: Local Wisdom, Indigenous People, Customary Forests, Forest Conservation

\begin{abstract}
ABSTRAK
Kearifan lokal masyarakat adat Cerekang khususnya dalam menjaga dan melestarikan hutan adat sangat di perlukan untuk kelangsungan hidup dan fungsi hutan. Tujuan dari penelitian ini adalah mengetahui kearifan lokal masyarakat adat Cerekang dan peranannya dalam menjaga dan melestarikan hutan adat . Penelitian ini dilaksanankan pada bulan September sampai bulan Desember 2020 di Desa Manurung Kecamatan Malili Kabupaten Luwu Timur. Data yang dikumpulkan terdiri atas bentuk kearifan lokal masyarakat adat Cerekang. Metode penelitian yang digunakan adalah wawancara mendalam dengan teknik bola salju (snowball sampling) kepada informan kunci meliputi pemangku adat, tokoh masyarakat, pemerintah desa dan masyarakat yang bermukim di sekitar hutan adat. Data dianalisis menggunakan teknik deskriptif kualitatif. Hasil yang diperoleh yaitu kearifan lokal masyarakat adat Cerekang berupa pembagian wilayah adat untuk upacara adat yang dilakukan oleh pemangku adat, anjuran dan larangan dalam memasuki hutan adat secara sembarangan serta beberapa mitos yang apabila dilanggar akan merusak ekosistem lingkungan dan mendatangkan bencana. Kearifan lokal ini sangat berperan dalam menjaga kelestarian hutan adat Cerekang karena masyarakat adat Cerekang sangat menjunjung tinggi kearifan lokal yang ada. Masyarakat adat mempercayai jika ada kearifan lokal yang di langgar maka ada sanksi maupun bencana yang akan datang
\end{abstract}

Kata Kunci : Kearifan Lokal, Masyarakat Adat, Hutan Adat, Kelestarian Hutan 


\section{PENDAHULUAN}

Hutan adat merupakan hutan yang berada dalam wilayah masyarakat hukum adat. Pengertian hutan adat merujuk pada status kawasan hutan. Status hutan adat merupakan bagian dari hutan hak, pada tahun 2012 Mahkamah Konstitusi memenangkan gugatan judicial review terhadap undang -undang kehutanan yang termaktub dalam putusan Nomor 35 / PUU-X / 2012. Mahkamah menganggap ketentuan hutan adat dalam undang-undang tersebut bertentangan dengan konstitusi. Kemudian statusnya dikukuhkan sebagai milik masyarakat adat, bukan hutan negara. Sehingga hutan hak terdiri dari hutan yang berada di atas tanah perseorangan/ badan hukum, dan merupakan hutan yang berada pada wilayah masyarakat hukum adat (Arizone, 2013).

Hutan adat Cerekang ditetapkan berdasarkan SK No.286/X/2019 tentang Pengakuan dan Perlindungan yang di sahkan oleh Bupati Luwu Timur pada tanggal 10 Oktober 2019. Menjaga dan melestarikan Hutan Adat Cerekang dilakukan oleh pemangku adat, kelembagaan adat, masyarakat adat Desa Manurung, Wija Tau Cerekang (WTC), dan aparat Desa Manurung. Hutan Adat Cerekang yaitu hutan adat atau pangngale' ada' tomatoa atau hutan keramat sama sekali tidak boleh dimanfaatkan/dikelolah karena mengandung nilai sejarah orang-orang yang dimuliakan oleh masyarakat adat Cerekang, seperti Sawerigading dan Batara Guru. Sedangkan Masyarakat Adat Cerekang adalah komunitas yang tinggal di Dusun Cerekang, Desa Manurung yang terletak sekitar $550 \mathrm{~km}$ dari kota Makassar, dibentuk tahun 1997 dengan luas wilayah 10,25 km2 dan terdiri dari empat dusun yaitu Cerekang, Pabeta, Wulasi dan Tomba (Iriani, 2019)

Masyarakat Adat Cerekang, Desa Manurung, sangat mentaati peraturan-peraturan adat yang berlaku, terutama di sekitar Hutan Adat Cerekang dengan melakukan ritual-ritual adat setiap tahun. Kegiatan dalam Hutan Adat Cerekang dilakukan oleh pemangku adat, kelembagaan adat, masyarakat adat Desa Manurung, Wija Tau Cerekang (WTC), dan aparat Desa Manurung. Hutan Adat Cerekang merupakan hutan adat yang sering disebut pangngale' ada' tomatoa atau hutan keramat tidak boleh dimasuki dengan sembarangan karena mengandung nilai sejarah orang-orang yang dimuliakan oleh masyarakat adat Cerekang, seperti Sawerigading dan Batara Guru. Masyarakat Adat Cerekang adalah komunitas yang tinggal di Dusun Cerekang, Desa Manurung yang terletak sekitar $550 \mathrm{~km}$ dari kota Makassar, dibentuk tahun 1997 dengan luas wilayah $10,25 \mathrm{~km}^{2}$ dan terdiri dari empat dusun yaitu Cerekang, Pabeta, Wulasi dan Tomba.

Kearifan lokal adalah berbagai nilai yang diciptakan, dikembangkan dan dipertahankan oleh masyarakat yang menjadi pedoman hidup mereka. Berbagai nilai yang diciptakan, dikembangkan dan dipertahankan oleh masyarakat yang menjadi pedoman hidup mereka. (local wisdom) kearifan setempat. Jadi kearifan lokal dapat dipahami sebagai gagasan dan pengetahuan setempat yang bersifat bijaksana, penuh kearifan, bernilai baik dan berbudi luhur yang dimilki, dipedomani dan dilaksanakan oleh seluruh anggota masyarakat (Apriyanto, 2008).

Kearifan lokal merupakan suatu bentuk kearifan lingkungan yang ada dalam kehidupan bermasyarakat di suatu tempat atau daerah, jadi merujuk pada lokalitas dan komunitas tertentu (Suhartini, 2009). Beberapa kasus pelestarian hutan adat oleh masyarakat dapat dicermati bahwa kearifan lokal masyarakat di dalam pelestarian hutan pada kenyataannya telah membawa dampak yang positif bagi kelestarian hutan, karena masyarakat mempunyai tingkat ketergantungan dari hutan tersebut, sehingga pola-pola pemanfaatan lebih mengarah pada kelestarian.

Di Kabupaten Luwu Timur masih banyak ditemukan yang sangat kuat memegang, mempertahankan dan mengamalkan nilai-nilai leluhur budayanya. Komunitas Adat Cerekang ini terdapat di Desa Manurung, Kecematan Malili, dari semua Desa di wilayah Kecematan Malili, hanya Cerekang yang penduduknya masih sangat kuat memegang tradisi lisan yang bersumber pada I Lagaligo. Ketaatan pada tradisi tersebut tampak dari beberapa tempat berupa bukti dan hutan yang masih dianggap "keramat". Akan tetapi sistem kepercayaan 
masyarakat adat Cerekang pada dasarnya merupakan tradisi-tradisi yang masih dilakukan oleh masyarakat. Berdasarkan tradisi-tradisi tersebut ditemukan berbagai perpaduan dengan ajaran Islam. Boleh jadi ini merupakan sinkritisme antara ajaran Islam dengan kepercayaan masyarakat setempat. Kepercayaan animisme dan dinamisme sangat kental pada masa-masa pra Islam di daerah Cerekang, yang kemudian para penyiar agama islam berusaha mengislamkan para peladang yang ada dihutan dan menariknya kembali ke desa, serta mengharamkan bentu-bentuk kegiatan animisme dan dinamisme yang dianut oleh masyarakat .para penyiar Islam membawa budaya baru dan pemikiran-pemikiran yang lebih maju, serta mengenalkan budaya bersawah, mengajarkan membaca dan menulis.

Tujuan dari penelitian ini adalah mengetahui kearifan lokal masyarakat adat Cerekang dan peranannya dalam menjaga dan melestarikan hutan adat. Penelitian ini diharapkan dapat menjadi gambaran bagi masyarakat untuk tetap memperhatikan kearifan-kearifan lokal agar kondisi hutan tetap terjaga dan lestari.

\section{METODE PENELITIAN}

Penelitian ini dilakukan selama dua bulan yaitu pada bulan Oktober sampai November 2019 di Desa Manurung, Kecematan Malili, Kabupaten Luwu Timur.

Alat yang digunakan dalam penelitian ini terdiri dari buku catatan, alat tulis menulis,

perekam pada saat wawancara dan camera untuk keperluan dokumentasi.. Bahan yang digunakan dalam penelitian ini yaitu kuisioner. Pengumpulan data dilakukan dengan observasi, wawancara dan studi pustaka. Jenis data yang digunakan dalam penelitian ini antara lain: (1) Data primer merupakan data yang diperoleh secara langsung dengan observasi dan wawancara semi terstruktur menggunakan kuisioner terbuka yang dibuat sebelumnya. Data yang dikumpulkan terdiri dari sejarah hutan adat Cerekang, struktur kelembagaan adat, aturan adat, dan kearifan lokal masyarakat adat (aturan, norma dan sanksi, serta nilai). (2) Data sekunder merupakan data yang diperoleh secara tidak langsung. Data sekunder penelitian ini meliputi profil desa, studi pustaka berupa jurnal atau laporan penelitian yang terkait dengan kearifan lokal masyarakat adat dalam melestarikan Hutan Adat.

Populasi dalam penelitian ini adalah masyarakat yang tergabung dalam kelembagaan adat Cerekang di Hutan Adat Desa Manurung Kecamatan Malili, yang terdiri dari Wija Tau Cerekang (WTC), Pemangku Adat, Tokoh masyarakat, Pemerintah Desa dan masyarakat sekitar hutan adat Cerekang. Sampel dalam penelitian ini adalah responden yang merupakan bagian dari populasi. Metode penentuan responden menggunakan metode bola salju (Snowball Sampling).

Sampel dalam penelitian ini adalah responden yang merupakan bagian dari populasi (sebagian atau wakil populasi yang diteliti). Responden penelitian yang diambil sebagai sumber data dan dapat mewakili seluruh populasi. Adapun penentuan jumlah responden yang digunakan dalam penelitian ini yaitu dengan menggunakan metode Snowball Sampling. Responden yang menjadi informasi kunci pada penelitian ini adalah Ketua Kelembagaan Adat desa Manurung. Analisis Data yang digunakan yaitu analisis kualitatif dengan menggunakan metode Deskriptif. 


\section{HASIL DAN PEMBAHASAN}

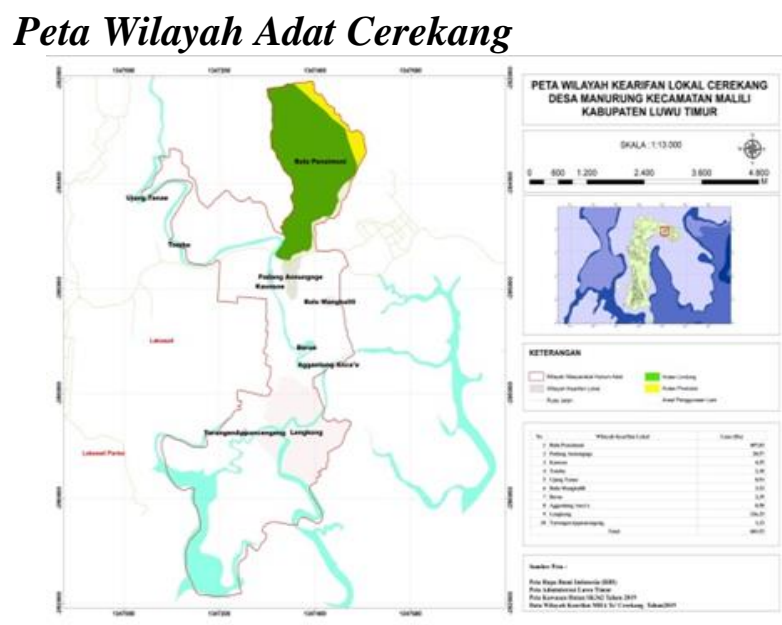

Gambar 1 . Peta Wilayah Adat Cerekang

\section{Sejarah Hutan Adat Cerekang}

Kata Cerekang berasal dari kata cerre yang berarti dituangkan dimana ketika diturunkannya Latonge' Langi' yang bergelar Batara Guru ke Ponseweni untuk menjadi manusia pertama dan sekaligus Raja pertama Alekawa yaitu luwu dengan pusat kerajaan di Ware' dengan syarat bahwa ia harus mengambil sebagai permaisuri puteri tertua "benua bawah" (Toddang Toja) la Matimmang Guru Ri Salleng. Turunan merekalah yang akan menjadi penguasa benua tengah (Alekawa: Luwu). Setelah Latonge' Langi' diturunkan ke Alekawa dalam bambu gading yang besar dan tiba di Ussu diantar inang pengasuh dan selirnya beserta pengikutnya, maka mulailah Alekawa ditata sehingga terciptalah tanaman, hewan, gunung, padang sungai, dan danau (Aci, 2014).

Cerekang merupakan suatu kampung yang terletak di Desa Manurung. Masyarakat Cerekang masih memiliki kepercayaan dan kebudayaan leluhur yang masih dipertahankan hingga saat ini. Resistensi kepercayaan dan kebudayaan masyarakat Cerekang membedakannya dengan masyarakat yang berada disekitarnya. Cerekang menyimpan banyak cerita dan budaya, khususnya terkait dengan asal mula kerajaan Luwu. Cerekang dianggap sebagai tempat pertama turunnya Batara Guru, yang kemudian menjadi pusat pemerintahan kerajaan Luwu yang pertama (Pangerang, 2006). Oleh karena itu, masyarakat cerekang menganggap dirinya sebagai kakak dari Raja Luwu. ware adalah istilah pemukiman Raja Luwu yang pertama di Ussu.

Masyarakat To Cerekeng percaya bahwa mereka adalah keturunan dari Batara Guru. Batara Guru menjadi pemimpin yang menjamin keseimbangan duniawi dan pengabdian kepada alam dan Sang Penguasa Alam. Ajaran Batara Guru yang masih dipelihara oleh To Cerekeng adalah prinsipprinsip kedamaian antar sesama manusia dan alam untuk menghindari kekacauan, seperti cara bercocok tanam tanpa merusak alam, memakan daging binatang dan ikan tanpa membuat hewan binasa dan tanpa membuat air sungai keruh.

Legenda masyarakat Cerekang bermula dari Tomanurung dan Sawerigading sebagai cikal bakal manusia di dunia sekarang. Berkembang sebuah pemahaman di Cerekang bahwa semua umat manusia dari berbagai ras dipercaya berasal dari Sawerigading. Mereka yang hidup sekarang adalah anak cucu Sawerigading yang wajib menjaga Cerekang, baik siklus hidup maupun tempat yang dipercaya sebagai asal mula sumber pangan dan kebutuhan masyarakat, seperti sungai dan hutan.

Masyarakat Cerekang memiliki adat istiadat yang sangat kuat dan masih dipegang teguh oleh masyarakat yang bersangkutan. Mereka hidup seperti masyarakat biasa pada umumnya, bergaul dengan masyarakat luar, dan menyekolahkan anak-anaknya sampai pada perguruan tinggi. Namun mereka tetap taat tradisi dan kepercayaan mereka secara turuntemurun. Dari pembicaraan penulis dengan salah seorang mantan kepala dusun, menurutnya ketaatan untuk menjalankan tradisi leluhur adalah sesuatu yang tidak bisa ditawartawar lagi. Hal ini terwujud dengan masih banyaknya pantangan-pantangan yang berlaku dalam masyarakat Cerekang, sehingga mereka memiliki banyak pantangan atau larangan yang tidak boleh dilanggar seperti larangan mengonsumsi pisang kapok, yang oleh masyarakat setempat dikenal dengan pisang manurung. Pisang tersebut dianggap pamali untuk dikonsumsi, mulai dari buah, pisang sampai daunnya tidak dapat digunakan oleh masyarakat Cerekang karena apabila larangan tersebut dilanggar. Mereka memercayai akan mendapat sanksi berubah musibah. 
Dari penuturan To Cerekeng, bahwa dulu wilayah To Cerekeng meliputi sebagian Tampinna, Manurung, Atue sampai Ussu. Namun, jika dilihat secara ikatan spritual yang dihubungkan dengan 10 lokasi penting wilayah adat To Cerekeng mencakup 3 wilayah administrasi desa di Kecamatan Malili Kabupaten Luwu Timur, yaitu Manurung, Atue, dan Ussu. Pusat aktivitas Cerekeng saat ini berada di Dusun Cerekeng, Desa Manurung yang terletak di sekitar Sungai Cerekeng. Dalam interaksi dengan masyarakat luar, masyarakat adat to' Cerekeng tidak menutup diri dengan mengutamakan nilai-nilai sipakatau (memanusiakan manusia), sipakainge' (saling mengingatkan), sipakalebbi (saling menghargai), sipakaraja (saling membantu), dalam artianya menghargai yang lebih tua dan menghormati yang muda. Juga semakna dengan kata kemana kaki dipijak, kesitu bumi dijunjung.

Pemimpin adat di Cerekang dikenal dengan istilah Pua sebagai pemangku adat dalam masyarakat Cerekang. Pua merupakan orang pilihan dalam masyarakat Cerekang, sehingga tidak sembarang orang bisa menjabat sebagai pua. Pada masyarakat cerekang dikenal ada pua laki-laki dan ada pua perempuan dan kedua orang tersebut bukan suami istri. Pua merupakan pemegang kekuasaan tertinggi dalam masyarakat adat, pua tidak dipilih oleh masyarakat, namun melalui wangsit dari sembilan orang, selain itu pua tidak diwariskan secara turun temurun seperti sebuah kerajaan.

\section{Struktur dan Tugas Pemangku Adat To' Cerekang}

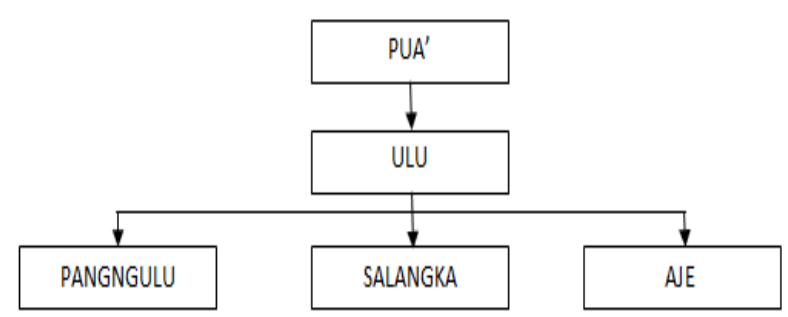

Gambar 2. Struktur Pemangku Adat To' Cerekang

Tugas dan fungsi masing-masing pemangku adat :
Pua' adalah sebagai pemegang kekuasaan tertinggi dalam masyarakat adat. $P u a^{\prime}$ ini menjadi sumber informasi dari penguasa langit, sebagai penghubung bumi (dunia tengah), dunia atas (langit) dan dunia bawah (air). Pua' menerima kehendak sang penguasa kehidupan dan menterjemahkan berupa aturan yang mengikat tentang apa yang boleh dan tidak boleh dilakukan oleh To Cerekeng. Pua' terdiri dari Pua' lakilaki dan Pua' perempuan (tetapi mereka bukan pasangan suami istri). Pua' laki-laki bertugas mengurusi hubungan manusia dengan Sang Pencipta/ Dewatae. Pua' perempuan mengurus masalah adat yang berhubungan dengan bumi/alam.

1. Ulu disebut wakil Pua' yang mengurusi segala sesuatu yang terkait pihak luar To' Cerekeng baik dari pemerintah maupun masyarakat luar. Ulu juga berpasangan laki-laki dan perempuan tetapi bukan pasangan suami istri. Pangngulu disebut pelaksanaan sosial menangani segala kepentingan masyarakat adat, seperti pembukaan lahan dan ritual adat ia tidak berpasangan dikarenakan sudah ditentukan oleh ketua adat.

2. Salangka sebagai pembantu pangngulu tidak berpasangan dikarenakan hanya membantu pangngulu untuk mengurusi pembukaan lahan dan ritual-ritual adat.

3. Aje sebagai hubungan luar. Menangani urusan umum iya juga tidak berpasangan dikarenakan sudah ditentukan oleh ketua adat.

Lembaga adat ini dibentuk sebagai respon atas kondisi sosial di Wilayah Adat To' Cerekeng, dipilih berdasarkan musyawarah mufakat masyarakat adat To' Cerekang dan bertugas sebagai penyambung antara pihak luar dengan komunitas adat To' Cerekeng maupun pemangku adat selain pemerintah setempat. Mekanisme Pengambilan Keputusan tertinggi berada di Pemangku adat (Pua'), hasil musyawarah yang dilakukan oleh lembaga adat disampaikan ke pemangku adat untuk diputuskan. 


\section{Pembagian wilayah adat Cerekang}

Beberapa wilayah dalam hutan adat Cerekang yang juga dijadikan tempat ritual komunitas adat Cerekang antara lain :

1. Ujung Tanae merupakan suatu wilayah hamparan hutan yang dipergunakankan sebagai tempat ritual yang berhubungan dengan bencana alam khususnya banjir.

2. Tomba, merupakan suatu wilayah hutan adat yang dipergunakan sebagai tempat ritual jika berhubungan dengan pertanian/perkebunan.

3. Ponsewoni, merupakan hutan adat yang sangat utama yang oleh masyarakat dipercaya sebagai mula tana/bola tanah atau permulaan tanah. Yang dipergunakan sebagai tempat ritual maggawe (meminta) reski dan keselamatan.Disinilah tempat pengambilan air suci yang dipergunakan dalam proses upacara-upacara adat yang dilaksanakan di kedatuan Luwu, misalnya mapacokkong ri baruga.

4. Kasosoe, merupakan wilayah hutan adat yang dipergunakan sebagai tempat ritual meminta kepintaran, dan juga dijadikan sebagai tempat pemakaman.

5. Birue, merupakan wilayah hutan adat yang dipergunakan sebagai tempat ritual meminta awaraniang atau keberanian.

6. Mangkulili, merupakan wilayah hutan adat yang dipercaya komunitas adat Cerekang, sebagai tempat pohon Wallenrenge ,yang dibuat perahu yang digunakan Sawerigading menuju Tanah Cina.

7. Lengkong, merupakan suatu wilayah hutan adat (nipah dan bakau) yang dipergunakan sebagai tempat ritual mengenai kelautan atau hasil laut.

8. Padang Annungnge, merupakan wilayah/lokasi pelaksanaan ritual yang berupa tanaman padang dan rawa yang berkaitan dengan persawahan.

9. Aggatung'ngeng Ance'e, merupakan wilayah hutan yang memiliki fungsi mappesabbi (tempat meminta izin) sebelum melakukan acara ritual adat di Lengkong.

\section{Turungeng Appancangengnge,} merupakan wilayah yang terdiri dari hutan bakau dan nipa yang berfungsi sebagai lokasi pelaksanaan ritual yang berhubungan dengan kelautan atau hasil laut.

Selain pembagian wilayah adat berdasarkan tujuan adat masing-masing, terdapat juga kompleks pemakaman masyarakat Cerekang yang di sebut Kasosoe, berada dalam wilayah hutan adat. Juga sering dijadikan sebagai tempat ritual komunitas adat meminta kepintaran. Pembagian ini terdiri dari 3 lokasi yang berbeda berdasarkan keturunan atau status dalam masyarakat yaitu :

1. Makam Pua' yaitu kuburan atau makam yang khusus di peruntukkan bagi semua Pua' yang telah meninggal.

2. Makam Wija Pua' atau keturunan Pua' yaitu makam yang di peruntukkan bagi semua keluarga atau yang mempunyai keturunan Pua'.

3. Makam orang biasa atau masyarakat biasa, yang diperuntukkan bagi masyarakat Cerekang pada umumnya atau masyarakat luar yang meninggal di wilayah Cerekang.

Keunikan di pekuburan atau pemakaman ini yaitu nisan yang harus terbuat dari kayu yang tidak bertuliskan nama tanggal dan tahun orang yang meninggal. Apabila nisan tersebut lapuk (hancur) maka tidak diperkenankan untuk diganti lagi atau dibiarkan saja. Ketika ada salah satu masyakarat Cerekang meninggal, warga yang hendak menghantar mayat perlu mematuhi beberapa ketentuan berupa : harus memakai sarung, naik perahu (pincara), tidak memakai alas kaki dan tutup kepala. Lokasi pemakaman merupakan hutan belantara yang masih asli karena semenjak dahulu terjaga kelestariannya karena adanya kearifan lokal yang secara turun temurun di laksanakan.

\section{Kearifan Lokal Masyarakat Adat Cerekang berdasarkan Aturan, Norma dan Nilai serta Sanksi yang berkaitan dengan hutan Adat}

Hutan adat di Cerekang tidak boleh dimasuki secara sembarangan. Jika ada yang ingin memasuki hutan adat harus melalui ritual adat dan izin pemangku adat, karena wilayah 
hutan adat Cerekang sudah dibagi oleh pemangku adat sesuai dengan tujuan masingmasing seperti bukit pensemoni, merupakan wilayah hutan adat yang dipercaya sebagai mula tanah/bola (tanah/rumah). Mengunjungi tempat ini bisa melalui darat maupun sungai karena mempunyai anak sungai yang bisa dilalui perahu dan harus seizin pua' untuk masuk dalam hutan adat tersebut

Sebagian masyaraat Cerekang memahami bahwa mengunjungi puncak Bulu pensomoni di tepi sungai Cerekang sama dengan melakukan ibadah haji, karena disitulah batara guru pertama turun kedunia. Pensomoni merupakan tempat yang suci dan tidak bisa dijangkau tanpa ritual dan izin dari pua', bahkan masyarakat yang pernah melihat tempat yang suci tersebut bisa di hitung jari. Bulu pensowoni ini sebagai salah satu perwujudan dunia, dengan demikian menunjukkan bahwa hutan adat Cerekang tidak boleh dimasuki oleh masyarakat adat maupun masyarakat luar tanpa seizin pua' dan melalui ritual-ritual sebagai bentuk penghargaan kepada leluhur mereka.

Bagi masyarakat adat Cerekang hutan juga merupakan sumber lahan atau cadangan lahan di masa depan. Sementara itu, Sungai Cerekang merupakan sumber air rumah tangga untuk keperluan minum, memasak, mencuci dan mandi. Hutan keramat merupakan tempat ritual adat yang penting bagi masyarakat Cerekang. Ada dua ritual yang dilaksanakan di hutan keramat yaitu mappaenre ota dan mappasolon gang buaya. Mappaenre ota diadakan jika ada orang yang ingin mappaleppe satinja (melepas hajat), sementara ritual mappasolongang buaya diadakan setahun sekali untuk doa keselamatan bagi masyarakat Cerekang. Di samping itu, juga ada ritual pengambilan air suci yang merupakan salah satu syarat dalam acara masuk istana bagi Raja Luwu.

Kearifan lokal masyarakat adat Cerekang berdasarkan aturan, norma dan nilai, serta sanksi terdiri atas :

a. Aturan adat yang berhubungan dengan wilayah adat dan sumber daya alam

1.Tidak melakukan kegiatan di Pangngale ade' tomatua (Hutan keramat) kecuali ritual yang dipimpin oleh pemangku adat, karena mengandung nilai sejarah orang-orang yang dimuliakan oleh masyarakat adat Cerekang, seperti Sawerigading dan Batara Guru. Jika ada yang melanggar maka diberikan sanksi berupa ipalumpangi capere (dikeluarkan dari wilayah adat To' Cerekang) dan acara ritual adatnya tidak diakui oleh pemangku adat.

2. Tidak diperkenankan melakukan penebangan dalam Hutan adat. Masyarakat mempercayai bahwa jika ada yang melanggar maka arwah para leluhur menurunkan kutukan. Kutukan itu dapat berupa penyakit yang diderita oleh orang yang melanggar bahkan bisa mendatangkan bencana alam di Desa Manurung.

b. Aturan adat yang berhubungan dengan pranata sosial

1. Masyarakat To' Cerekang yang ikut mengantar mayat ke tempat pemakaman di wajibkan memakai sarung (mallipa'), naik perahu (pincara), tidak memakai alas kaki, dan tidak memakai penutup kepala. Jika ada yang melanggar, maka tidak di perbolehkan ikut mengantar mayat, apabila tetap pergi maka orang tersebut akan menerima kutukan dari dari arwah para leluhur berupa penyakit serta bisa mendatangkan bencana alam di Desa manurung.

2. Mewajibkan anak yang baru lahir dimandikan di Sungai Cerekang yang mengalir melalui hutan adat. Jika tidak dimandikan maka anak tersebut akan mendapat kutukan berupa penyakit dari arwah para leluhur

3. Masyarakat To' tidak memakan utti manurung (pisang kapok), jika ada yang melanggar maka akan mendapat kutukan berupa penyakit, dan rezeki yang terhambat.

4. Masyarakat To' Cerekang tidak diperbolehkan membangun rumah permanen dari batu. Jika ada yang tetap ingin membangun rumah dari batu harus membangun diluar wilayah adat Cerekang. 


\section{|KESIMPULAN}

Dari hasil penelitian di Desa Manurung dapat ditarik kesimpulan bahwa Kearifan local sangat berperan dalam menjaga dan tetap melestarikan hutan adat Cerekang. Dapat dilihat dari kehidupan masyarakat adat To' Cerekang yang masih memegang teguh kepercayaan turun temurun dan adat istiadat. sampai sekarang ini. Nilai-nilai budaya lokal seperti pembagian wilayah hutan adat yang dipercaya keramat, dan larangan/pamali oleh masyarakat adat To' Cerekang meyakini bahwa jika dilanggar maka akan menimbulkan kutukan atau bala dari para leluhur. Kondisi hutan adat hingga kini masih Lestari karena adanya kearifan lokal yang di junjung tinggi oleh masyarakat adat Cerekang.

\section{DAFTAR PUSTAKA}

Aci, 2014. Mengenal Budaya Suku Cerekang yang Mensakralkan Hutan dan Sungainya. Kabupaten Luwu Timur.

AMAN (Aliansi Masyarakat Adat Nusanatara), 2019. Kearifan Lokal Masyarakat Hukum Adat To Cerekeng. Luwu Timur
Apriyanto, 2008. Hubungan Kearifan Lokal Masyarakat Adat dengan Pelestarian Lingkungan Hidup. Universitas Pendidikan Indonesia. Bandung.

Arizone, 2013. Kriteria Masyarakat (Hukum) Adat dan Potensi Implikasinya terhadap Perebutan Sumberdaya Hutan. PascaPutusan MK Nomor 35/PUUX/2012:Studi Kasus Kabupaten Kutai Barat, Kalimantan Timur

Iriani, 2019. Sistem Kepemimpinan Pua' pada Masyarakat Adat Cerekang. Balai Pelestarian Nilai Budaya Sulawesi Selatan.

Pangerang, A. 2006. Sinopsis Kirab Keraton Kerajaan Luwu (Langkanae), Festival Keraton Nusantara IV 2004 Di Yogyakarta.

Sugiyono, 2012. Memahami Penelitian Kualitatif. Alfabeta. Bandung.

Suhartini. 2009. Kajian Kearifan Lokal Masyarakat dalam Pengelolaan Sumberdaya Alam dan Lingkungan, Seminar Nasional Penelitian, Pendidikan dan Penerapan MIPA, Fakultas MIPA, Universitas Negeri Yogyakarta 